\title{
Ti-Mn-V 系水素吸蔵合金の水素化特性
}

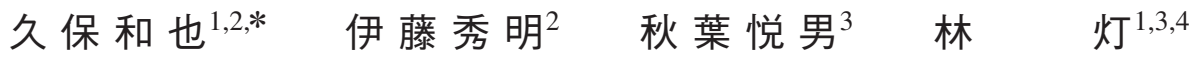

1九州大学大学院工学府水素エネルギーシステム専攻

2 株式会社日本製鋼所

3 九州大学水素エネルギー国際研究センター

4 九州大学エネルギー研究教育機構

J. Japan Inst. Met. Mater. Vol. 84, No. 3 (2020), pp. 99-108

Special Issue on Hydrogen and Materials Characteristic in Solids IV

(C) 2020 The Japan Institute of Metals and Materials

\section{Hydrogenation Properties in Ti-Mn-V Alloys}

\author{
Kazuya Kubo ${ }^{1,2, *}$, Hideaki Itoh ${ }^{2}$, Etsuo Akiba $^{3}$ and Akari Hayashi ${ }^{1,3,4}$ \\ ${ }^{1}$ Department of Hydrogen Energy Systems, Faculty of Engineering, Kyushu University, Fukuoka 819-0395 \\ ${ }^{2}$ The Japan Steel Works, Ltd., Tokyo 141-0032 \\ ${ }^{3}$ International Research Center for Hydrogen Energy, Kyushu University, Fukuoka 819-0395 \\ ${ }^{4} Q^{-P I T, ~ K y u s h u ~ U n i v e r s i t y, ~ F u k u o k a ~ 819-0395 ~}$
}

Various Ti-Mn-V based ternary alloys, known as $\mathrm{AB}_{2}$ type hydrogen storage alloys, were prepared and evaluated in order to clarify their crystal structures and hydrogen absorption/desorption properties. As a result, $\mathrm{Mn}$-rich alloys with $\mathrm{C} 14$ laves structure were found to show a small hysteresis loop on absorbing/desorbing hydrogen. Furthermore, the effect of doping $4^{\text {th }}$ and $5^{\text {th }}$ element atoms on Ti-Mn-V based ternary alloys were evaluated. Then, $\mathrm{Mn}$-rich $\mathrm{Zr}$ doped $\mathrm{Ti}-\mathrm{V}-\mathrm{Mn}$ alloys, like $\mathrm{Ti}_{30-\mathrm{x}} \mathrm{Zr}_{\mathrm{x}} \mathrm{V}_{15} \mathrm{Mn}_{50}$, revealed most effective hydrogen storage capacity. Finally, we have found that a cooling process of melted alloys is important for synthesizing more homogeneous alloys, and successfully developed $\mathrm{Ti}_{25} \mathrm{Zr}_{10} \mathrm{~V}_{15} \mathrm{Mn}_{50}$ with a rapid solidification process as one of the most effective hydrogen storage materials.

[doi:10.2320/jinstmet.JB201908]

(Received September 4, 2019; Accepted January 6, 2020; Published February 25, 2020)

Keywords: titanium-manganese-vanadium alloy, hydrogen storage material, $A B_{2}$ type

\section{1. 緒言}

近年，再生可能エネルギーと水素エネルギーの融合が，エ ネルギー眝蔵の観点から注目されている。本研究では, 室温 付近で大量かつコンパクトに貯蔵できる, 高圧ガス保安法適 用外の $1 \mathrm{MPa}$ 未満の圧力範囲で扱える, 水素化物という固 形の形で水素を貯蔵できるなどの特徵を有する水素吸蔵合金 による水素貯蔵に着目している，現在では，水素吸放出特性 を示す圧力-組成-等温線図 $(\mathrm{P}-\mathrm{C}-\mathrm{T}$ 線図)において, 室温付 近で数気压の平衡解離圧を有し，且つプラトー部の平坦性お よびヒステリシスループの差が小さい(ヒステリシス特性が 良好な) $\mathrm{AB}_{5}{ }^{1)}$ 型合金が最も適した合金だと考えられている. しかしながら，水素吸蔵合金の本格的な利用に向けては，水 素吸蔵合金のさらなる高性能化が必須で, プラトー部の平坦 性およびヒステリシス特性が良好で, 有効水素移動量の大き な合金の開発が求められている.

その中でも $\mathrm{AB}_{2}{ }^{2,3)}$ 型合金は, 特に $\mathrm{Ti}$ と遷移金属の組合せ で得られる合金にて常温・常圧近傍に平衡解離圧を有するこ

\footnotetext{
* 九州大学大学院生 (Graduate Student, Kyushu University)
}

とが知られている。この中で $\mathrm{C} 14$ 型のラーベス相構造を有 し，化学画論組成から Ti リッチにした $\mathrm{TiMn}_{1.5}$ 合金が $293 \mathrm{~K}$ で $0.8 \mathrm{MPa}$ 程度の平衡解離圧を持ち ${ }^{2)}$, プラトー部の有効水 素移動量, プラトーの平坦性やヒステリシス特性等も比較的 優れていることから ${ }^{4)}$, 実用化に向けて種々の特性改善に関 する研究がなされてきた5-8).

本研究では, TiMn 系合金の中でも大きな最大水素吸蔵量 と優れた水素吸放出特性を有する $\mathrm{TiMnV}$ 三元系合金 ${ }^{9)}$ に着 目し, 実用上具備していなければならない有効水素移動量, $\mathrm{P}-\mathrm{C}-\mathrm{T}$ 線図上のプラトーの平坦性, ヒステリシス性等につ いて, 水素化特性の改善を目的として総括的に組成と結晶構 造との関係を調査するとともに，それぞれの結晶構造と水素 吸放出特性の相関性について考察した。また，更なる最大水 素吸蔵量の増大, ならびに有効水素移動量の増大を目的とし て, 添加元素の効果や作製プロセスの最適化について検討し た.

\section{2. 実 験 手 順}

\section{$2.1 T i M n V$ 系合金の合成}

$\mathrm{TiMnV}$ 三元系合金において, C14 ラーベス構造や BCC 構 
造など種々の結晶構造を持つ $\mathrm{TiMnV}$ 三元系合金を総括的評 価するために，Tiリッチ， Mnリッチ，Vリッチなどを含む Fig. 1 に示すような合金組成で，試料を作製した。

合成試料の原材料としては純度 99.8 mass\%のスポンジチ タン ((株) 高純度化学研究所製), 純度 99.9 mass \%の電解マ ンガン ((株) 高純度化学研究所製), 純度 99.7 mass\%の金属 バナジウム ( (株)レアメタリック製)を用いた。試料はいずれ も水冷銅ルツボを用い, Arアーク炉で溶製した. Mn を含む 試料の溶解においては, 溶解時に Mn のガス化により約 5\% 程度の重量減少が認められたため, Mn においてはあらかじ め所定の組成より $5 \%$ 増量させた秤量重量において溶解を実 施した. 試料重量は約 $100 \mathrm{~g}$ 程度とし, 直径 $30 \mathrm{~mm}$, 高さ $20 \mathrm{~mm}$ 程度のプリン形状の試料を溶製した.さらに溶解後, 組成の均質性を高めるために，シリコニット炉を用いて $\mathrm{Ar}$ ガス中で $1373 \mathrm{~K} ， 24 \mathrm{~h}$ の熱処理を施した。一部の試料につ いては，高温での安定相あるいは析出相の影響を調べるため に，1073-1373 K の間で種々熱処理条件を変化させた.

また，置換元素の影響を検討する目的で，C14 ラーベス構 造を安定的に持つ $\mathrm{Ti}_{35} \mathrm{Mn}_{50} \mathrm{~V}_{15}$ をベースに， $\mathrm{Ti}$ サイトを置換 した $\mathrm{Ti}_{35-\mathrm{x}} \mathrm{A}_{\mathrm{x}} \mathrm{Mn}_{50} \mathrm{~V}_{15}(\mathrm{x}=0 ， 5 ， 10) ， \mathrm{Mn}$ サイトを置換した $\mathrm{Ti}_{30} \mathrm{Zr}_{5} \mathrm{~V}_{15} \mathrm{Mn}_{45} \mathrm{~B}_{\mathrm{y}}(\mathrm{y}=0, \quad 5,10)$ や, $(\mathrm{Ti}, \mathrm{Zr})_{50-\mathrm{x}}\left(\mathrm{V}_{\mathrm{x}} \mathrm{Mn}_{50}\right)(\mathrm{x}=$ $5,10,15,17,20)$ で $\mathrm{V}$ 含有量の最適化を実施したもの, $\mathrm{Ti}_{40} \mathrm{Mn}_{60-\mathrm{x}} \mathrm{V}_{\mathrm{x}}(\mathrm{x}=15,10,5)$ の 3 種類の合金をベースに Ti の 一部を $\mathrm{Zr}$ で置換した合金を作製した。これらの合金の製造 方法，熱処理条件は，上記に示したのと同様の条件を用い た。ただし，一部の試料については，熱処理条件を変えた検 討も行った。

合成の過程において凝固を変化させる目的で, 急速凝固し た試料を合成した。最も良好な特性が得られている $\mathrm{Ti}_{35} \mathrm{Mn}_{50} \mathrm{~V}_{15}$ に $\mathrm{Zr}$ を置換した $\mathrm{Ti}_{35-\mathrm{x}} \mathrm{Zr}_{\mathrm{x}} \mathrm{Mn}_{50} \mathrm{~V}_{15}(\mathrm{x}=0, \quad 5,10)$ を検討組成とし，急冷凝固合金の作製には高周波溶解部, ロール部, 飛行管部等からなる日新技研 (株) 製水冷単ロール 式の急冷凝固装置 NEV-A5M を使用した。底部に 0.5-1 mm 程度の穴をあけた石英ノズルに，予めアーク溶解炬にて溶製 した合金を入れ， $10^{-3} \mathrm{~Pa}$ 程度まで真空引きし，その後 $\mathrm{Ar}$ を 大気圧程度まで導入し, 高周波溶解部にて合金を高周波溶解 した。合金が溶湯になったことを確認し，ノズル上部より $\mathrm{Ar}$ 圧 $\left(0.2 \mathrm{kgf} / \mathrm{cm}^{2}\right)$ をかけ, 湯をノズル下部にて $800 \mathrm{rpm}$ 高速 回転する水冷式 $\mathrm{Cu}$ ロールに噴射した。ここで，ロールとノ

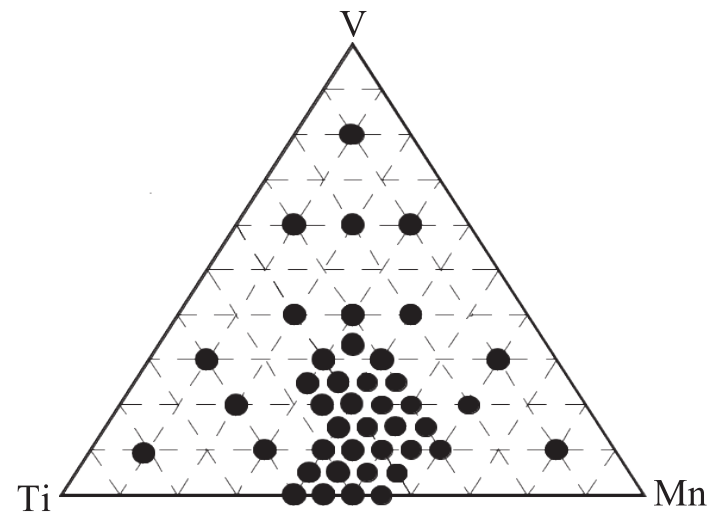

Fig. 1 Ti-Mn-V alloy compositions evaluated in this study.
ズルのギャップは $0.6 \mathrm{~mm}$ とした。噴射された湯をロールに 接触することにより急速に冷却し，飛行管部に集めること で, 厚さ数 $\mu \mathrm{m}-$ 数十 $\mu \mathrm{m}$ の薄片の試料を作製した.

\section{2 各種合金試料の材料解析}

得られた合金材料は，大気中にて粉砕した後，マックサイ エンス製 MXP18VAを用いたXRDにより，安定相の同定と 格子定数の解析を行った．合金材料の組成に関しては，溶解 後の試料を ICP 分析に供し, 目標組成と一致しているかど うかを確認した。

合金試料は結晶粒と結晶粒界とが明確になるまでエッチン グ処理を行った後，光学顕微鏡を用いて組織観察をおこなっ た. 電子線マイクロアナライザ(EPMA)を用いた元素分析も 行った.

\section{3 各種合金の初期活性化および水素吸放出特性評価}

得られた合金について初期活性化を行った後， $\mathrm{P}-\mathrm{C}-\mathrm{T}$ 測 定を行った. SUS304の高圧水素ガスタンク, 真空排気タン ク，反応容器，恒温浴槽などで構成された装置を用いて，容 器類や圧力計等から構成測定機器は全て恒温浴槽中で所定の 温度で一定に保つ構造を有し, 環境温度変化の影響はない状 態で, 反応容器の内容積約 $20 \mathrm{ml}$ に $\mathrm{g}$ の試料を封入して, 水素化に関する評価試験を実施した.

$673 \mathrm{~K}$ で 2 h 脱ガス処理後, $293 \mathrm{~K}, 5 \mathrm{MPa}$ で初期活性化を 行い,さらに数回の水素吸収・放出を繰り返した後， $293 \mathrm{~K}$ から $353 \mathrm{~K}$ の温度にて, $\mathrm{P}-\mathrm{C}-\mathrm{T}$ の測定を行った。 $\mathrm{P}-\mathrm{C}-\mathrm{T}$ 測 定は，0.001-5 MPa の圧力範囲にて行った．水素は公称純度 99.99999\%, 露点 203 K 以下の市販水素を用いた.

\section{3. 実験結果と考察}

\section{1 結晶構造と水素吸放出特性の相関性について}

XRD 解析結果より，熱処理温度 $1373 \mathrm{~K}$ において， Fig. 1 の組成の合金は, Fig. 2 に示すように, BCC 構造単相， C14 ラーベス構造単相, $\mathrm{BCC}$ 構造 + C14 ラーベス構造混相に分 類できることが分かった.

ここでは，具体的にそれぞれの結晶構造を有する合金とし て, $\mathrm{Ti}_{20} \mathrm{Mn}_{20} \mathrm{~V}_{60}, \mathrm{Ti}_{40} \mathrm{Mn}_{30} \mathrm{~V}_{30}, \mathrm{Ti}_{40} \mathrm{Mn}_{50} \mathrm{~V}_{10}$ の 3 種の合金を

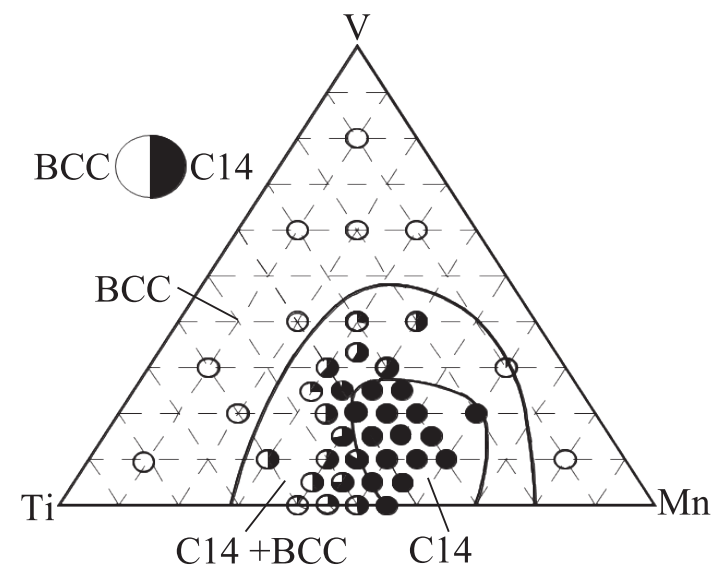

Fig. 2 Crystal structures of different Ti-Mn-V alloys with the heat treatment at $1373 \mathrm{~K}$ 
用いて詳細な解析結果について述べる。それぞれの XRD プ ロファイルをFig. 3 に示している. $\mathrm{Ti}_{20} \mathrm{Mn}_{20} \mathrm{~V}_{60}$ 合金では $\mathrm{BCC}$ 単相構造を示し格子定数は $3.03 \AA$ であり, $\mathrm{Ti}_{40} \mathrm{Mn}_{50} \mathrm{~V}_{10}$ 合金では C14 ラーベス相単相構造を示し格子定数は $\mathrm{a}$ 軸が $4.89 \AA, \mathrm{c}$ 軸が $8.02 \AA$ と算出された. 一方, $\mathrm{Ti}_{40} \mathrm{Mn}_{30} \mathrm{~V}_{30}$ 合金

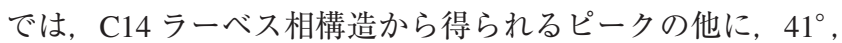
$59^{\circ}$ に BCC 構造から得られるものとみられる特徵的なピーク が表れており，本合金は C14 ラーベス構造と BCC 構造との 混相であることが確認された. C14 ラーベス相構造の格子定 数は $\mathrm{a}$ 軸が $4.92 \AA, \mathrm{c}$ 軸が $8.04 \AA$ であり, $\mathrm{BCC}$ 構造の格子定 数は $3.10 \AA$ と算出された.

次に, 3 種の合金の $\mathrm{P}-\mathrm{C}-\mathrm{T}$ 結果を Fig. 4 に示す. $\mathrm{Ti}_{20} \mathrm{Mn}_{20} \mathrm{~V}_{60}$ のように $\mathrm{Ti}$ や $\mathrm{V}$ 含有量の大きな合金では, 大き な最大水素吸蔵量を示したものの, 有効水素移動量やプラ トー部の平坦性, ヒステリシス特性が良好ではないという $\mathrm{BCC}$ 構造特有の $\mathrm{P}-\mathrm{C}-\mathrm{T}$ 特性 ${ }^{10)}$ が得られた。また, $\mathrm{Ti}_{40} \mathrm{Mn}_{50} \mathrm{~V}_{10}$ のように $\mathrm{V}$ 含有量が少なく $\mathrm{Ti} / \mathrm{Mn}$ 比が小さい合 金では, 最大水素吸蔵量は小さいものの, 特にヒステリシス 特性が良好であるという $\mathrm{C} 14$ ラーベス構造特有の $\mathrm{P}-\mathrm{C}-\mathrm{T}$ 特 性が得られた。一方, $\mathrm{Ti}_{40} \mathrm{Mn}_{30} \mathrm{~V}_{30}$ のように $\mathrm{C} 14$ ラーベス構 造と $\mathrm{BCC}$ 構造の混相では, 最大水素吸蔵量は $\mathrm{Ti}_{20} \mathrm{Mn}_{20} \mathrm{~V}_{60}$ と $\mathrm{Ti}_{40} \mathrm{Mn}_{50} \mathrm{~V}_{10}$ の中間程度であるものの, $\mathrm{BCC}$ 構造の合金と 同等の水素圧から吸蔵を開始し，またプラトー部が消失する という $\mathrm{P}-\mathrm{C}-\mathrm{T}$ 特性が得られた。

水素吸蔵合金を用いて有効に水素を吸放出するためには, プラトー部の平坦性やヒステリシス特性が良好である C14 ラーベス構造単相が重要であることが明かになったことか ら, 更なる $\mathrm{P}-\mathrm{C}-\mathrm{T}$ 特性の改善のため, 熱処理温度を変化さ
せたときの結晶構造と水素化特性について検討した。熱処理 温度を $1173 \mathrm{~K}$ とした場合，熱処理温度を低下させることに より, Fig. 3 に比べて, Ti や V リッチ側の組成で C14 ラー ベス構造単相の領域は広がることが認められた。

そこで, 高温領域でも C14 ラーベス構造単相が示された $\mathrm{Ti}_{40} \mathrm{Mnn}_{45} \mathrm{~V}_{15}$ と高温域では $\mathrm{C} 14$ ラーベス構造と $\mathrm{BCC}$ 構造との 混相を示すが, $1173 \mathrm{~K}$ の熱処理を施して C14 ラーベス単相

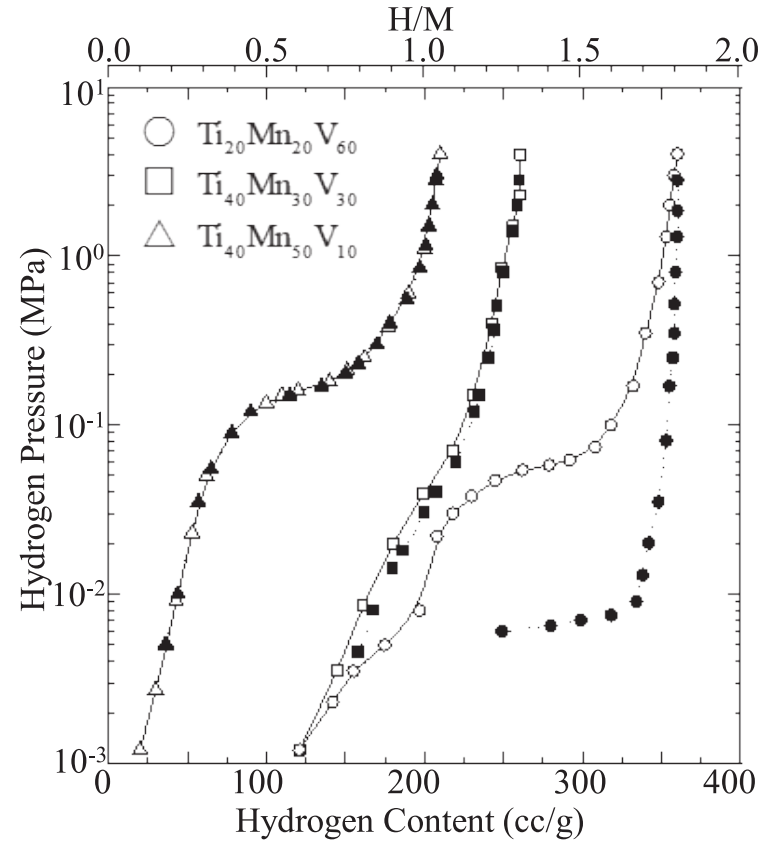

Fig. 4 PC-isotherms at $293 \mathrm{~K}$ for $\mathrm{Ti}_{20} \mathrm{Mn}_{20} \mathrm{~V}_{60}, \mathrm{Ti}_{40} \mathrm{Mn}_{30} \mathrm{~V}_{30}$, and $\mathrm{Ti}_{40} \mathrm{Mn}_{50} \mathrm{~V}_{10}$, where open and closed symbols are absorption and desorption, respectively.
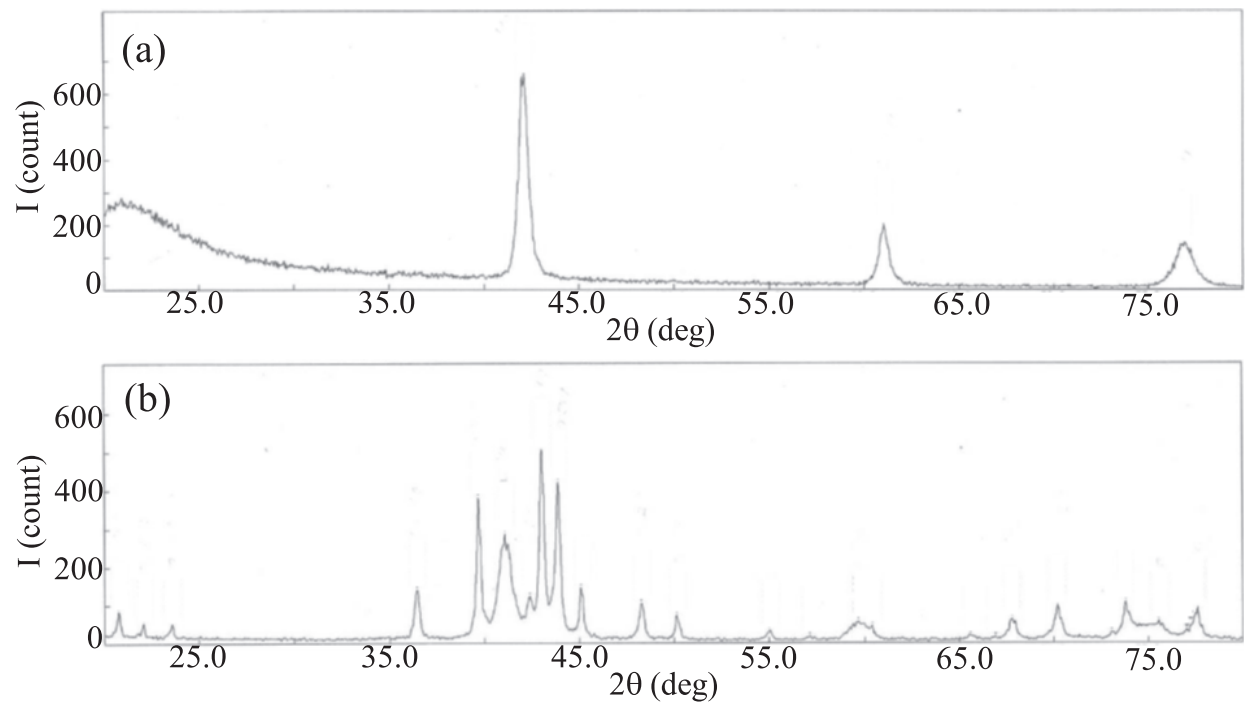

(c)

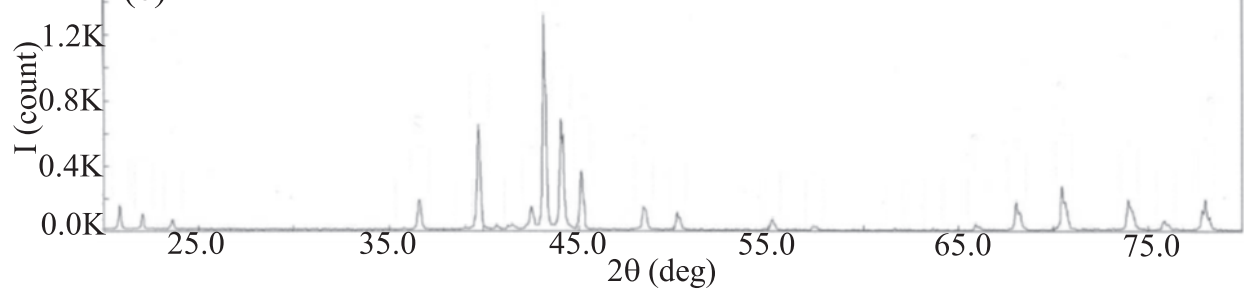

Fig. 3 XRD patterns of (a) $\mathrm{Ti}_{20} \mathrm{Mn}_{20} \mathrm{~V}_{60}$, (b) $\mathrm{Ti}_{40} \mathrm{Mn}_{30} \mathrm{~V}_{30}$, and (c) $\mathrm{Ti}_{40} \mathrm{Mn}_{50} \mathrm{~V}_{10}$. 
構造に変化させた $\mathrm{Ti}_{45} \mathrm{Mn}_{35} \mathrm{~V}_{20}$ の 2 種類に対して, その場 $\mathrm{X}$ 線回折装置を用いて水素化時の構造変化について検討した. また, XRD プロファイルから得られた格子体積と水素貯蔵 量の関係および $\mathrm{P}-\mathrm{C}-\mathrm{T}$ 特性についても検討した.

Fig. 5 に, 高温域でもC14 ラーベス単相構造が示された $\mathrm{Ti}_{40} \mathrm{Mn}_{45} \mathrm{~V}_{15}$ に $1173 \mathrm{~K}$ の熱処理を施した試料ついて, 水素圧 を 0-0.2 MPa の範囲で印加した時のその場 X 線回折測定で 得られたプロファイルの変化を示す. C14 ラーベス構造から 得られるピークは水素圧を $0.02 \mathrm{MPa}$ まで上げると単純に低

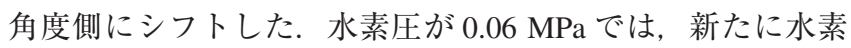
化物のピークが現われ, $0.2 \mathrm{MPa}$ まで高めると水素化物の ピークのみが現れた。 これら XRD プロファイルから得られ た格子体積と水素吸蔵量の関係及び $\mathrm{P}-\mathrm{C}-\mathrm{T}$ 線図を Fig. 6 に 示している. 水素吸蔵量が約 $90 \mathrm{cc} / \mathrm{g}$ になるまで格子体積は 直線的に増加し, $90 \mathrm{cc} / \mathrm{g}$ と $190 \mathrm{cc} / \mathrm{g}$ との間で $\alpha$ 相(金属相) のピークと $\beta$ 相 (水素化物相)のピークとが共存する領域が現 われた。 この二相共存領域は $\mathrm{P}-\mathrm{C}-\mathrm{T}$ 曲線のプラトーとも良 く一致した.

一方, 高温域では C14 ラーベス構造と BCC 構造との混相 を示すが, $1173 \mathrm{~K}$ の熱処理を施して C14 ラーベス単相構造 に変化させた $\mathrm{Ti}_{45} \mathrm{Mn}_{35} \mathrm{~V}_{20}$ 合金について, 水素圧を 0-0.2 $\mathrm{MPa}$ の範囲で印加した時の XRD プロファイルの変化を調べ た結果，水素圧をあげていくと C14 ラーベス構造から得ら れるピークは単純に低角度側にシフトしていった。 これら XRD プロファイルから得られた格子体積と水素吸蔵量の関 係及び $\mathrm{P}-\mathrm{C}-\mathrm{T}$ 線図を Fig. 7 に示す. 格子体積は吸蔵量とと もに単調増加し, 水素化物を形成することなく, 水素が固溶 状態で格子内に侵入していくことがわかった。これは $\mathrm{P}-\mathrm{C}-$ $\mathrm{T}$ 曲線の形状とも良く一致した.

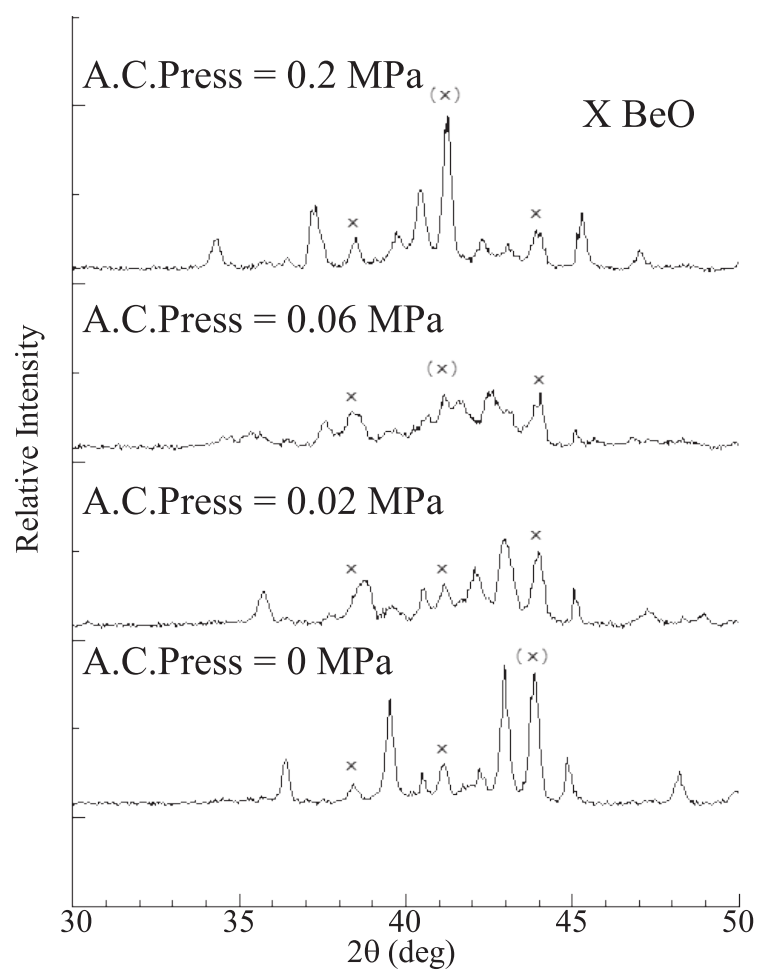

Fig. 5 XRD patterns of $\mathrm{Ti}_{40} \mathrm{Mn}_{45} \mathrm{~V}_{15}$ under the different hydrogen pressure.
このように同じ C14 ラーベス単相構造を持っていても水 素化に伴う結晶構造変化が大きく異なることが確認され，そ れが $\mathrm{P}-\mathrm{C}-\mathrm{T}$ 特性の違いに表れていることがわかった．Tiや $\mathrm{V}$ が比較的多い組成で $\mathrm{C} 14$ ラーベス単相構造を持つ合金が 水素化物を形成しにくくなる原因は，Ti， V リッチな組成に なることにより，一部の余剩 Ti が結晶中の Mn サイトを置 換し，結果的に Ti が結晶中で不規則配列するためだと考え られる. V も同様で, その原子半径は $\mathrm{Ti}$ と $\mathrm{Mn}$ の中間に位 置し，過剩に添加することによって Ti や Mnのサイトをい ずれも無秩序に置換するためだと思われる。一般に水素化物 相を形成する際は原子配置がきちんと決まっているが，Ti リッチあるいはV Vリッチな組成を持つ合金では, 組成配列 が不規則なものとなったため, 水素化物が形成しにくくなっ たと考えられる。
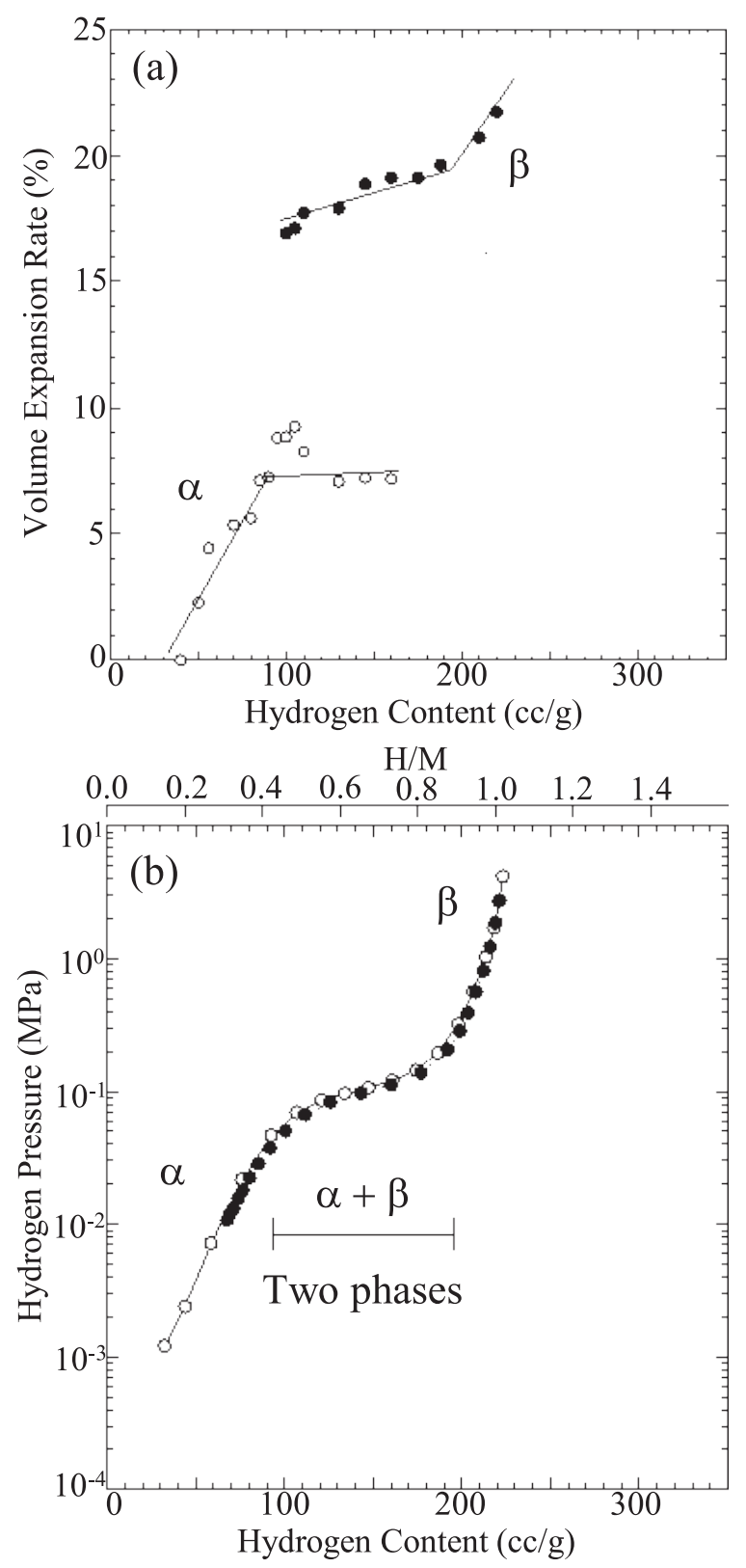

Fig. 6 Change in the lattice volume of $\mathrm{Ti}_{40} \mathrm{Mn}_{45} \mathrm{~V}_{15}$ with its corresponding PC-isotherm, where open and closed symbols are absorption and desorption, respectively. 


\section{2 添加元素の影響について}

\subsubsection{TiMnV 三元系合金の Ti サイトへの置換の検討}

TiMnV 三元系合金に第 4 元素を添加することで, 結晶構 造や水素吸放出特性への影響を検討した. TiMnV 三元系合 金の $\mathrm{Ti}$ サイトに, 水素との親和力があり, 且つ原子半径が $\mathrm{Ti}$ よりも大きい元素として $\mathrm{Zr}, \mathrm{Nb}, \mathrm{Hf}, \mathrm{Ta}$ を選択し, $\mathrm{Ti}_{35} \mathrm{Mn}_{50} \mathrm{~V}_{15}$ 合金の $\mathrm{Ti}$ サイトに 5 at\%置換した結果，作製さ れた合金は全て C14 ラーベス構造単相を有することが確認 された.これらの四元系合金の $\mathrm{P}-\mathrm{C}-\mathrm{T}$ 測定結果を行った結 果, $\mathrm{Ta}, \mathrm{Nb}$ を置換した合金は, ベース合金と比較して平衡 解離圧が上昇する傾向が見られた。 また, 水素固溶領域は減 少するものの, 最大水素吸蔵量も大きく減少することから, 結果として有効水素移動量は減少した. 一方, Hf, Zr を置 換した合金は, ベース合金と比較して平衡解離圧が大きく減
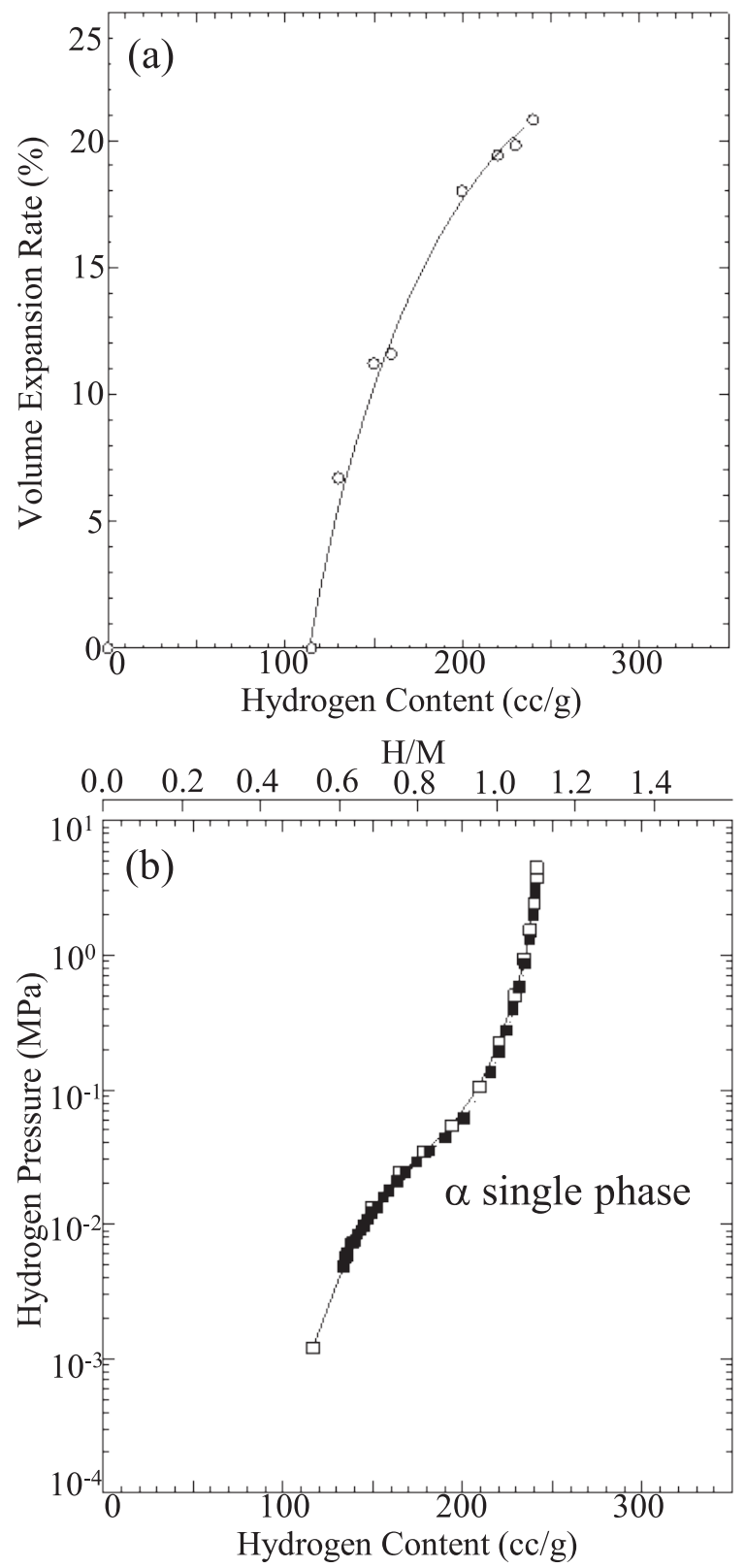

Fig. 7 Change in the lattice volume of $\mathrm{Ti}_{45} \mathrm{Mn}_{35} \mathrm{~V}_{20}$ with its corresponding PC-isotherm, where open and closed symbols are absorption and desorption, respectively.
少する傾向が見られた，Hf を置換した合金では，水素固溶 領域は殆ど変化せず, 最大水素吸蔵量が減少したために有効 水素移動量は減少した。しかし唯一 Zr を置換した合金では, 水素固溶領域が減少して最大水素吸蔵量が増加したため, 有 効水素移動量が増加することがわかった.

Fig. 8 に, 種々元素の置換量に対する格子体積の変化と, 置換最大水素吸蔵量と有効水素移動量の変化を示す. Z r や Hf のように Tiよりも Goldschmidt 半径の大きな元素が置換 されると，格子体積が大きく増加した。一方， $\mathrm{Nb}$ や $\mathrm{Ta}$ のよ うに Ti と Goldschmidt 半径が同じ元素が置換されると, 格 子体積はほとんど変化しなかった。一般的に水素化物の安定 性は, 周期表の 3 族 $>4$ 族 $>5$ 族の順に高いことが知られて いる ${ }^{11)}$. 本実験で安定に水素化物を形成する 4 族の Ti に対 して 5 族の $\mathrm{Nb}$ や $\mathrm{Ta}$ を置換した合金では，水素化物の安定 性が低下することから，格子体積はほぼ同等であったものの 水素吸蔵能力は大幅に減少し, 平衡解離圧が上昇したと考察 している.

\subsubsection{TiZrVMn 四元系合金の Mn サイトへの置換の検討}

上記の結果より, 最大水素吸蔵量および有効水素移動量の 観点から, $\mathrm{Zr}$ 置換のみで良好な特性が得られることが明か になったことから，更なる特性改善の目的で, Zr を置換し た TiZrVMn 四元系合金の Mn サイトに種々元素を置換した 合金を作製した.Mnよりも Goldschmidt 半径の大きい元素 の置換は, 格子定数を大きくすることにより, 水素の占有开 イトを大きくし吸蔵量が増加すると予測し, TiZrVMn 四元 系合金の Mn サイトにMnよりも Goldschmidt 半径の大きな 元素である Moまたは Alを 5 at \% 置換した. X 線回折測定 により, どちらの五元系合金も, 結晶構造は C14 ラーベス
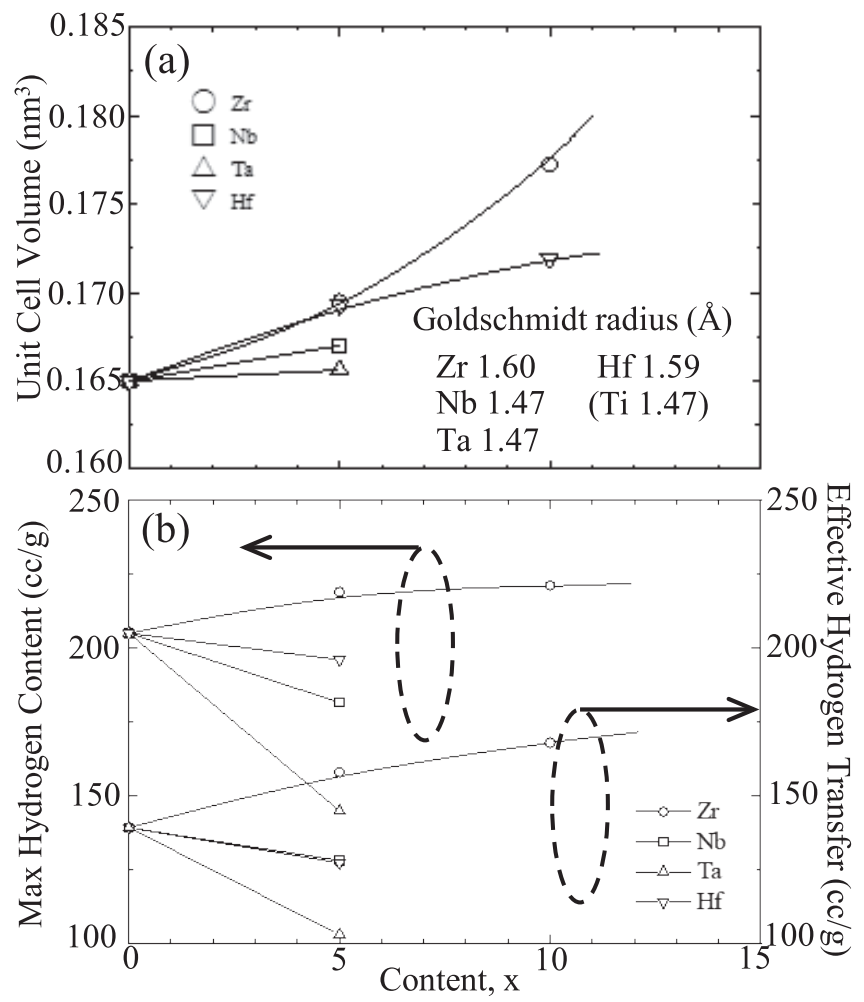

Fig. 8 (a) Unit cell volume and (b) maximum hydrogen content and effective hydrogen transfer of $\mathrm{Ti}_{35-\mathrm{x}} \mathrm{A}_{\mathrm{x}} \mathrm{V}_{15} \mathrm{Mn}_{50}$, where $\mathrm{A}$ stands dopants. 
構造であることが確認された。これらのサンプルの水素吸放 出特性を評価した結果, Mo もしくは $\mathrm{Al}$ の置換により水素 固溶領域が増加し, 最大水素吸蔵量も減少したため, 有効水 素移動量は大きく減少した. 更にプラトー部の平坦性も悪化 した，そこで，TiZrVMn 四元系合金の Mnサイトに Mnより も Goldschmidt 半径の小さな元素である $\mathrm{Cu}$ と $\mathrm{Fe}$ を 5-10 at \% 置換した。その結果, $\mathrm{P}-\mathrm{C}-\mathrm{T}$ 特性の変化において, $\mathrm{Fe}$ もしくは $\mathrm{Cu}$ を置換すると平衡圧が上昇する傾向が見られ た。 また，水素固溶領域は大きく変化しなかったが，最大水 素吸蔵量が減少したことから, 結果として有効水素移動量は 減少した。ここで $\mathrm{Cu}$ を置換した合金の $\mathrm{P}-\mathrm{C}-\mathrm{T}$ 特性を見る と, プラトー部の初期の段階では傾きが平坦になるが, 中間 部から曲線が立ち始めている傾向が確認された.

Fig. 9 に第 5 元素を置換したときの格子体積の変化を示 す. Mnよりも Goldschmidt 半径の大きい $\mathrm{Al}$ を置換すると, 格子体積が増加した. 一方, Mnよりも Goldschmidt 半径の 小さい $\mathrm{Fe}$ や $\mathrm{Cu}$ を置換すると, 格子体積が減少した。一般 的に, 水素吸蔵合金の平衡解離圧は格子体積が増大すると低

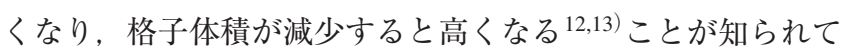
いることから, $\mathrm{P}-\mathrm{C}-\mathrm{T}$ 特性と比較してもこれらの結果は妥 当と考えられる。方 Mo を置換すると, Mnよりも Goldschmidt 半径が大きいにも関わらず, 格子体積が小さくなる という現象が見られた。この原因は明らかとはなっていない が, Mo 元素特有の現象と考えている.

\subsubsection{TiMnV 三元系合金への $\mathrm{Zr}$ 置換の最適化：Ti, V リッ チな組成の合金の Ti サイトへの置換}

以上のように TiMnV三元系合金に種々元素を置換したも のの, 唯一 $\mathrm{Zr}$ の置換が有効水素移動量の増加に対して効果 が見られた。 そこで, 更なる有効水素移動量の増加を目論
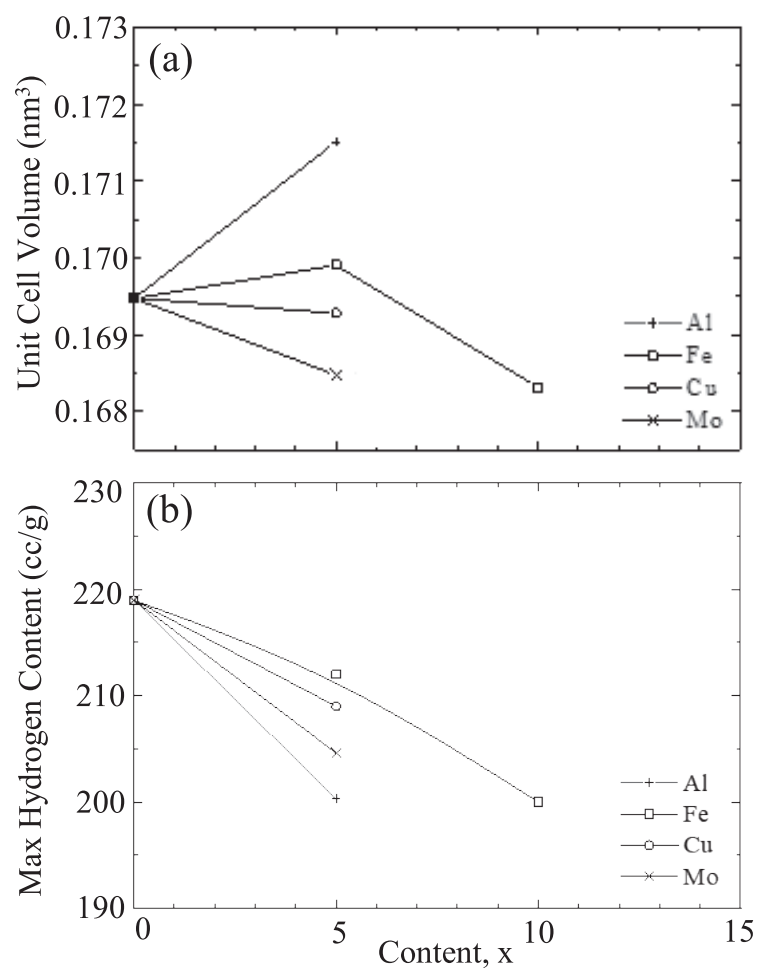

Fig. 9. (a) Unit cell volume and (b) maximum hydrogen content of $\mathrm{Ti}_{30} \mathrm{Zr}_{5} \mathrm{~V}_{15} \mathrm{Mn}_{45} \mathrm{~B}_{5}$, where B stands dopants.
み, $\mathrm{C} 14$ ラーベス構造単相合金の中で $\mathrm{Ti}, \mathrm{V}$ リッチな組成の 合金への Zr 置換を試みた。具体的には，熱処理条件を 1373 $\mathrm{K}$ とし， $\mathrm{Ti}_{40-\mathrm{X}} \mathrm{Zr}_{\mathrm{X}} \mathrm{Mn}_{45} \mathrm{~V}_{15}(\mathrm{X}=0 ， 5 ， 10)$ 合金を作製した. いずれの合金においても, BCC 構造の相が析出することな く, C14 ラーベス構造単相であることを確認した. 水素吸放 出特性を評価した結果, $\mathrm{Zr}$ 置換量とともに平衡水素圧は大 きく低下した。また，今回の組成では，Zr 置換に伴う有効 水素移動量の増加傾向は認められず, 逆にプラトー部の幅が 小さくなり, 有効水素移動量が減少する結果となった。 この ことから, Ti や V リッチな組成の合金に対しては, $\mathrm{Zr}$ 置換 は有効水素移動量の増大化には, 必ずしも有効でないことが わかった。

3.2.4 TiMnV 三元系合金への $\mathrm{Zr}$ 置換の最適化 : Mn リッチ な組成の合金の Ti サイトへの置換

これらの結果を踏まえ, 逆にMnリッチないくつかの合金 に対して $\mathrm{Zr}$ 置換の効果を調べた. $\mathrm{P}-\mathrm{C}-\mathrm{T}$ 特性において, $\mathrm{Ti}$, $\mathrm{V}$ リッチな組成への置換の場合と同様に $\mathrm{Zr}$ 置換により平衡 解離圧の低下が認められた。ささらに，プラトー部の平坦性は 悪化しているものの, 明らかに $\mathrm{Zr}$ の置換により有効水素移 動量は増大する傾向が認められた。

このように, $\mathrm{Ti}$ の一部を $\mathrm{Zr}$ で置換する効果は, $\mathrm{TiMnV}$ 系 合金の組成によって異なり，Ti， V リッチな組成の合金に対 しては有効水素移動量を低下させ，逆にMnリッチな合金に 対しては高める効果があることがわかった.

$\mathrm{Mn}$ リッチな合金への $\mathrm{Zr}$ 置換が有効水素移動量を高める 効果が確認できたことから, $\mathrm{Ti}_{25} \mathrm{~V}_{30} \mathrm{Mn}_{45}, \mathrm{Ti}_{25} \mathrm{~V}_{25} \mathrm{Mn}_{50}$, $\mathrm{Ti}_{20} \mathrm{~V}_{30} \mathrm{Mn}_{50}$ においても, $\mathrm{Zr}$ 置換を検討した. $\mathrm{X}$ 線回折測定 の結果より, どの合金についても C14 ラーベス構造単相が 得られたものの, $\mathrm{Ti}_{25} \mathrm{~V}_{25} \mathrm{Mn}_{50}$ ベースの合金以外は, ピーク がかなりブロード化しており，アモルファスライクな構造に なっていることがわかった，また， $\mathrm{Zr}$ 置換により, $\mathrm{Zr}$ 置換 前の合金と比べて格子定数が増大することが確認された。 こ れらの $\mathrm{P}-\mathrm{C}-\mathrm{T}$ 測定を行ったところ, $\mathrm{Zr}$ 置換前は水素吸蔵能 力を示さなかった $\mathrm{Ti}_{25} \mathrm{~V}_{25} \mathrm{Mn}_{50}$ と $\mathrm{Ti}_{20} \mathrm{~V}_{30} \mathrm{Mn}_{50}$ ベースのもの でも $\mathrm{Zr}$ 置換によって水素の吸蔵が認められた。 これは $\mathrm{Zr}$ 置 換により格子体積が増大し, 水素占有サイトが水素を吸蔵す るに十分なポテンシャルを得たためと考えられる. しかしプ ラトー部の傾きは大きく, ヒステリシス特性も良好なものは 得られなかった。

Mn，Vリッチ組成において今回得られた結果をもとに, $\mathrm{TiMnV}$ 三元系合金ならびに TiZrMnV 四元系合金の格子定数 と水素吸蔵量との相関性について Fig. 10 によとめている. 参考にこれまでで最も大きい有効水素移動量が得られている $\mathrm{Ti}_{35} \mathrm{~V}_{15} \mathrm{Mn}_{50}$ 合金についても合わせて示している.ここで白 丸が三元系合金を, 黒丸が三元系合金に Zr を置換した四元 系合金について示す．Fig. 10 から，TiMnV 系合金において は, 格子体積がおよそ $163 \mathrm{~nm}^{3}$ を境にして水素吸蔵が可能か 不可能かの境界となっていることがわかった，さらに格子定 数がおよそ $173 \mathrm{~nm}^{3}$ 以上になると, XRD プロファイルにお いてピークがブロードになり，アモルファス構造に近くなる ことから $\mathrm{P}-\mathrm{C}-\mathrm{T}$ 特性におけるプラトー部の傾きが大きく なってしまうことがわかった。 以上のまとめより, プラトー 


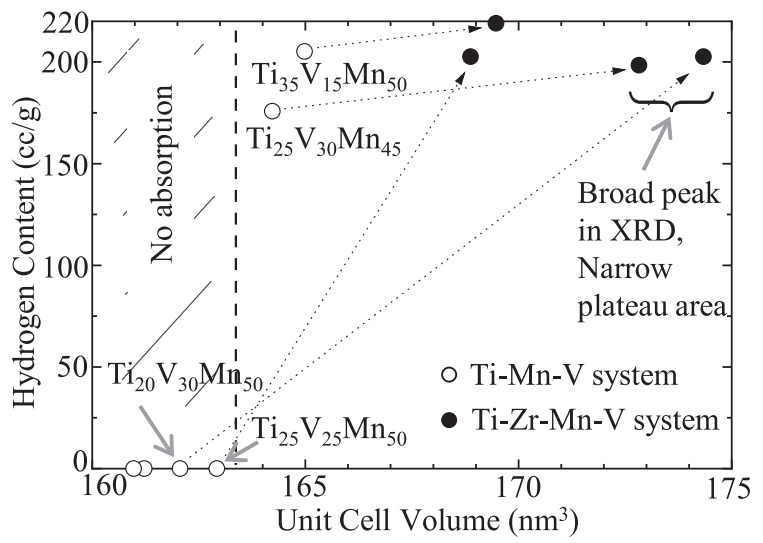

Fig. 10 A correlation between unit cell volume and hydrogen content.

特性の改善を考えた場合, 格子体積を $163-173 \mathrm{~nm}^{3}$ 範囲の中 に収めることが重要であることが明らかとなった。

\subsubsection{TiZrMnV 四元系合金の最適化： $\mathrm{V}$ 量の検討}

最後に, TiZrMnV 四元系合金に打いて最も良好な特性が 得られる組成の最適化に向けて, Mn 含有量を 50 at $\%$ と固定 して $\mathrm{V}$ 量を変化させた $(\mathrm{Ti}, \mathrm{Zr})_{50-\mathrm{x}} \mathrm{V}_{\mathrm{x}} \mathrm{Mn}_{50}$ 合金を作製した. 得られた合金はすべて C14 ラーベス構造単相を示した，P$\mathrm{C}-\mathrm{T}$ 測定により， $\mathrm{V}$ 量を増加させていくことで水素固溶領域 が大きく滅少していくことがわかったＶ含有量の増加に伴 い, Ti $\mathrm{Zr}$ といった水素との親和力が強い元素の割合も 減っていくことから最大水素吸蔵量も減少するものの, 有効 水素移動量は V 置換に伴い大きく増加することがわかった. Fig. 11 に $\mathrm{V}$ 量と格子定数挹よび最大水素吸蔵量との関係を まとめた， V 量の増加に伴い，格子体積は直線的に減少し, 最大水素吸蔵量も同様の減少傾向を示した。これは, 格子体 積が減少することで，水素占有サイトの大きさも小さくなる ためと考えられる. Fig. 12 に V 量と水素固溶領域掞よび有 効水素移動量の関倸について示す。ここで横軸上段には $\mathrm{A}$ 原子を $\mathrm{Ti}$ と $\mathrm{Zr}, \mathrm{B}$ 原子を $\mathrm{V}$ と $\mathrm{Mn}$ としたときの $\mathrm{AB}$ 比を示 した，水素固溶領域の幅は $\mathrm{V}$ 置換とともに減少していき， V が 15 at\%より多くなると傾きがゆるくなっていくことが確 認された。一方, 有効水素移動量は $\mathrm{V}$ 置換とともに大きく なっていき, 特に $\mathrm{A}$ 原子と $\mathrm{B}$ 原子の比が 1:2 となる付近, $\mathrm{V}$ 量で約 17 at\%付近で最大となることがわかった。この現象 は, $\mathrm{V}$ 量の増大に伴い初期には最大水素吸蔵量は減少する が，それ以上に $\alpha$ 相領域が減少するため有効水素移動量は 増大した. しかし $\alpha$ 相領域幅は V が 15 at\%付近でその減少 率を低下させるにも関わらず，最大水素吸蔵量の減少傾向は 変化しないため, 結果として有効水素移動量にピークが現れ たと考えられる. 有効水素移動量が最大となった V が 17 at\%付近の組成は, $\mathrm{Ti}$ や $\mathrm{Zr}$ を A 原子, $\mathrm{V}$ や Mn を B 原子と 仮定すると, $\mathrm{A}: \mathrm{B}=1: 2$ つまり化学量論組成となるところで あることがわかる.もともと V は水素との親和力が強い元 素ではあるが，現在 V が A サイト， B サイトどちらに占有 されているかはっきりしていないため上記のような仮定を 行ったが，A サイト，B サイト両方に $50 \%$ ずつ占有してい ると仮定すると $\mathrm{A}: \mathrm{B}=1: 1.5$ の比率で有効水素移動量は最大 值を示すこととなる。このように, 有効水素移動量は化学量

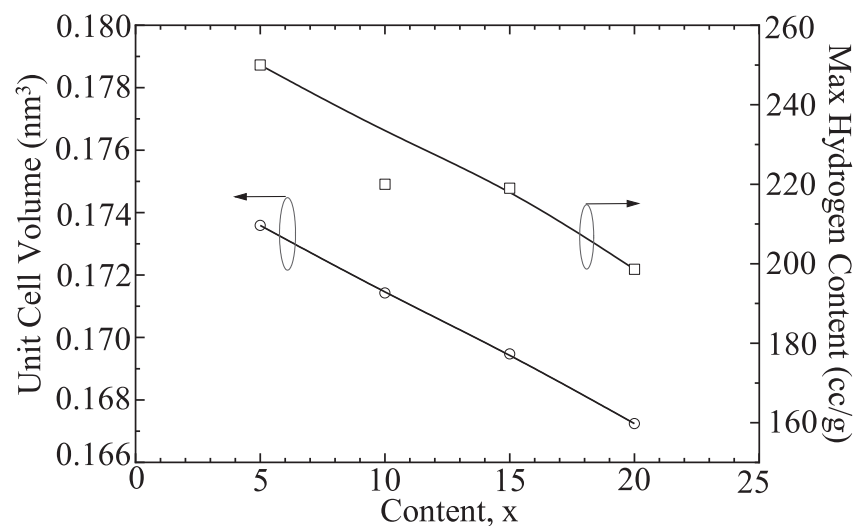

Fig. 11 A correlation between unit cell volume and maximum hydrogen capacity of $(\mathrm{Ti}, \mathrm{Zr})_{50-\mathrm{x}}\left(\mathrm{V}_{\mathrm{x}} \mathrm{Mn}_{50}\right)$.

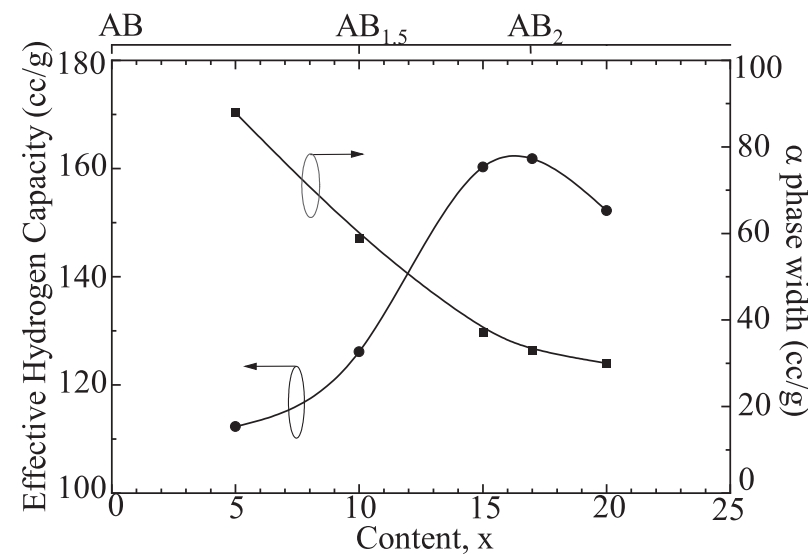

Fig. 12 A correlation between a phase width and effective hydrogen capacity of $(\mathrm{Ti}, \mathrm{Zr})_{50-\mathrm{x}}\left(\mathrm{V}_{\mathrm{x}} \mathrm{Mn}_{50}\right)$.

論組成近傍で最大值を示すことがわかった.

この結果を結晶構造と対応させて考察する. $\mathrm{AB}_{2}$ 組成を持 つ金属間化合物の中で，Ti や Mnをべースとした合金は C14 ラーベス構造 (六方晶構造)を有することが知られている. A と $\mathrm{B}$ の 2 種類の金属元素を剛体球として考えると, そのサ イズ比が 1.225 であったときに最密充填構造となり, サイズ 比が 1.225 に近いときにC14 ラーベス構造の結晶構造が生じ る.したがって C14 ラーベス構造を有する合金は, A, B 原 子の広い組成範囲で存在する場合が多く, C14 ラーベス構造 を有する水素吸蔵合金としては $\mathrm{TiMn}_{1.5}$ が知られている。こ のように原子半径の異なる 2 種類の原子の寸法比をうまく働 かせて適当な充填構造をとることによって, ひずみエネル ギーを利得する特徵を有している. C14 ラーベス構造では, $\mathrm{Ti}$ や Zr のように水素と親和力の強い原子 (A 原子) が入るサ イト及び水素との親和力が強くない原子 ( $\mathrm{B}$ 原子)が入るサイ トが存在する。このような組成配列が規則的な構造の中で は, A 原子が 2 個, B 原子が 2 個でつくられる A2B2 サイト に水素はまずトラップされると考えられている14). しかし 組成配列が不規則になり, 例えば A 原子がリッチの組成に なると， A 原子は $\mathrm{A}$ サイトのみならず $\mathrm{B}$ サイトをも占有す るようになると考えられる，そのような組成では，水素の占 有サイトには A 原子が 3 つと $\mathrm{B}$ 原子が 1 つで作られる $\mathrm{A} 3 \mathrm{~B}$ サイトや A 原子が 4 つで作られるような非常に安定な A4 サ イトができ，そこにまず水素が占有されるようになると考え 
られる. Fig. 13 に $\mathrm{P}-\mathrm{C}-\mathrm{T}$ の模式図を示す. 水素が $\mathrm{A} 2 \mathrm{~B} 2$ サ イトから占有する場合の $\mathrm{P}-\mathrm{C}-\mathrm{T}$ 曲線が図のようになると仮 定すると, A 原子が増えて安定な A3B サイトや A4 サイト から水素が占有される場合, そのサイトのポテンシャルが安 定で低いため, 初期の平衡圧が大きく下がると考えられる. 従って, $\mathrm{A}$ 原子リッチの組成を持つ合金では水素固溶領域が 広がると考えられる。

\section{3 急冷凝固の影響について}

3.2 節では, 最も有効水素移動量の多い合金の組成として $\mathrm{Ti}_{35-\mathrm{X}} \mathrm{Zr}_{\mathrm{x}} \mathrm{V}_{15} \mathrm{Mn}_{50}$ 合金が得られたことから,さらにサンプル 合成条件の影響を検討した. Fig. $14 に \mathrm{Ti}_{35-\mathrm{X}} \mathrm{Zr}_{\mathrm{x}} \mathrm{V}_{15} \mathrm{Mn}_{50}$ 合金 の $\mathrm{Zr}$ 量を変化させたときの $\mathrm{P}-\mathrm{C}-\mathrm{T}$ 特性を示す. $\mathrm{Ti}_{25} \mathrm{Zr}_{10} \mathrm{~V}_{15} \mathrm{Mn}_{50}$ に関しては, 熱処理温度が $1373 \mathrm{~K}$ から 1473 $\mathrm{K}$ に変更されている， $\mathrm{Zr}$ 置換量を増大させるほど有効水素 移動量は増大するものの, プラトーの傾きは大きくなる傾向 になることが確認された。 そこで, EPMA 観察を $\mathrm{Ti}_{25} \mathrm{Zr}_{10} \mathrm{~V}_{15} \mathrm{Mn}_{50}$ について行った. Fig. 15 に示すように, $\mathrm{Zr}$ 成分が偏析していることが認められた。 Mnは比較的均一に 分布していたが, Zr 成分が多い箇所では Ti P V 成分が少な

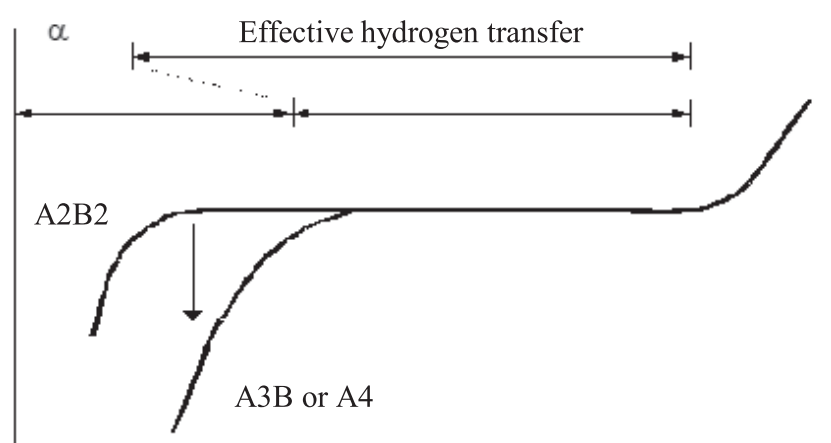

Fig. 13 Schematic diagram showing PC-isotherm depending on hydrogen occupation sites.

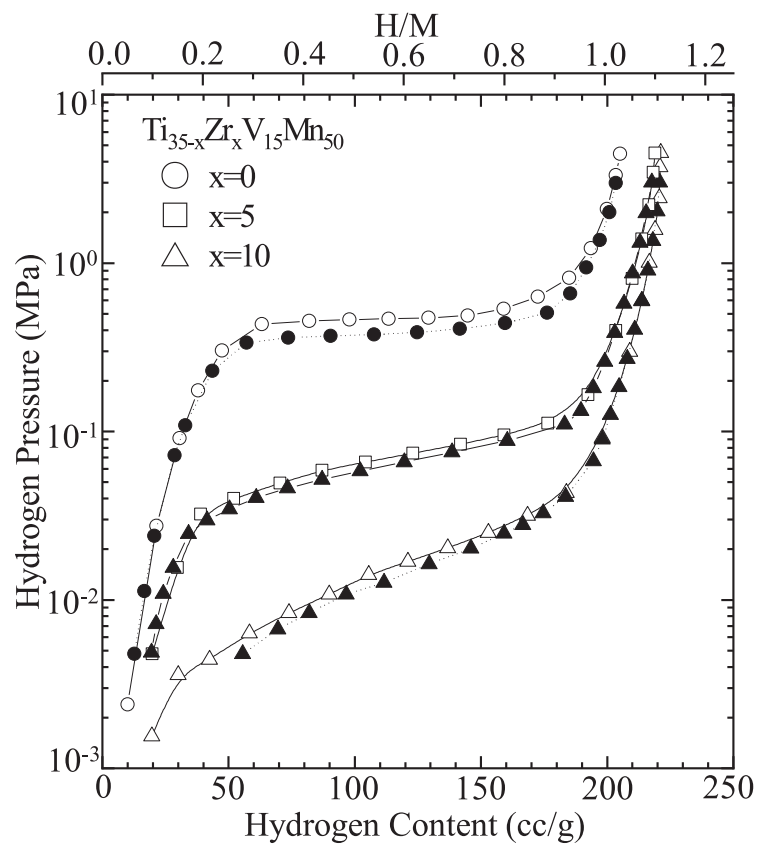

Fig. $14 \mathrm{PC}$-isotherms at $293 \mathrm{~K}$ for $\mathrm{Ti}_{35-\mathrm{x}} \mathrm{Zr}_{\mathrm{x}} \mathrm{V}_{15} \mathrm{Mn}_{50}$, where open and closed symbols are absorption and desorption, respectively.

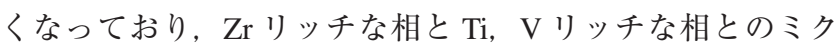
ロな混相になっていることが確認された．X線回折測定の結 果より，この合金は C14 ラーベス構造単相を示し異相の存 在は認められなかったが, この合金のプラトーの傾きが大き かったのは, Ti リッチ相と Zr リッチ相とのミクロな混在が 原因であることがわかった。 ここで， Zr と Ti とを比べると $\mathrm{Zr}$ の方が Goldschmidt 半径が大きく， Zr リッチ相と Tiリッ チ相では, 同じ $\mathrm{C} 14$ 構造でも結晶格子の体積が異なる $(\mathrm{Zr}$ リッチ相で格子体積が大きくなる)ことが考えられる，格子 体積は結晶格子内の水素占有サイトのポテンシャルを変化さ せるものであり, 水素の平衡解離圧に非常に関係のあること が知られているが, この合金のように Zr リッチ相, Ti, V リッチ相，母相とでミクロな混相が作られることにより，合 金内部のポテンシャルが多種類存在してしまうため, 水素の 平衡解離圧が 1 点に定まらず，プラトーの傾きが斜めになっ てしまったと考えられる．この傾向は $\mathrm{Zr}$ の置換量が増える ほど増加することが考えられ，それが $\mathrm{Zr}$ 置換量の増大に伴 いプラトー部の平坦性が悪化した原因と考えられる.

そこで, 急冷凝固法を用いて更に冷却速度を上昇させるこ とで，Zrの偏析を改善し，合金成分の均質化を試みた．Fig. 16 に熱処理後，炉冷を施した合金と急冷凝固を施した合金 の XRD プロファイルを示す.どちらも主相は C14 ラーベス 構造単相であり，熱処理後炉冷を施した合金の格子体積は $177.2 \AA^{3}$ で, 急冷凝固を施した合金は $170.7 \AA^{3}$ と, 格子体積 が減少する傾向が見られた。また熱処理後炉冷を施した合金 は $40^{\circ}$ 付近に異相ピークが現れたが，急冷凝固を施すことに
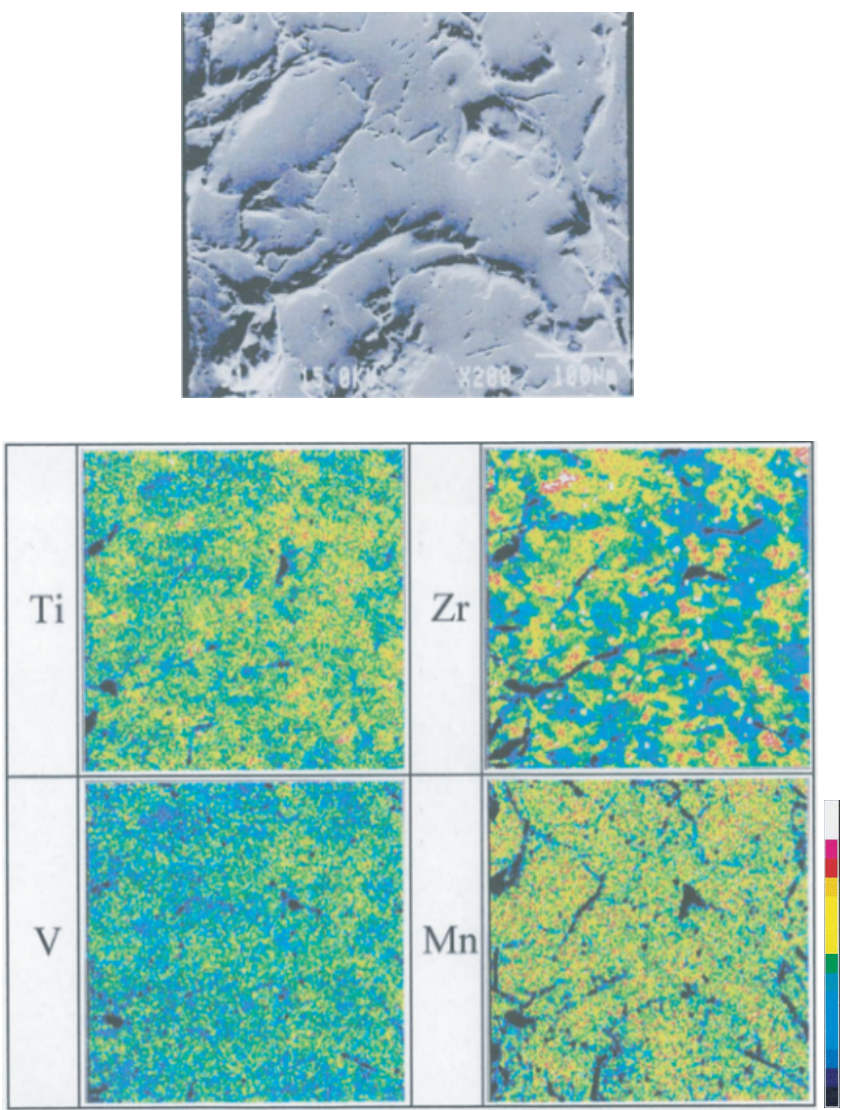

Fig. 15 An optical microscope image with the elemental analysis by EPMA of $\mathrm{Ti}_{25} \mathrm{Zr}_{10} \mathrm{~V}_{15} \mathrm{Mn}_{50}$ without a rapid solidification process. 


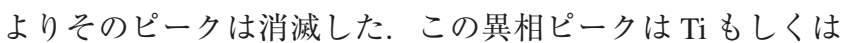
$\mathrm{Zr}$ の酸化物相からのピークであることが推定されるが, 急 冷凝固により合金成分の均質性が高まったことにより，この 相が消滅したと推測される. また, 急冷凝固により半価幅の 減少が認められ，合金成分が均質化されていることがここか らも推測された. Fig. 17 に急冷凝固した $\mathrm{Ti}_{25} \mathrm{Zr}_{10} \mathrm{~V}_{15} \mathrm{Mn}_{50}$ の 組織写真と EPMA 観察結果を示す. Fig. 15 と比較して, Zr の偏析は改善されていることが確認された。 また Ti, Vが リッチな相や Zr がリッチな相は, 急冷凝固合金では存在し ないことが確認された. 急冷凝固した $\mathrm{Ti}_{25} \mathrm{Zr}_{10} \mathrm{~V}_{15} \mathrm{Mn}_{50}$ の P-C-T 線図を Fig. 18 に示す. 急冷凝固法を用いることによ り, 最大水素吸蔵量や有効水素移動量を変化させずに, プラ
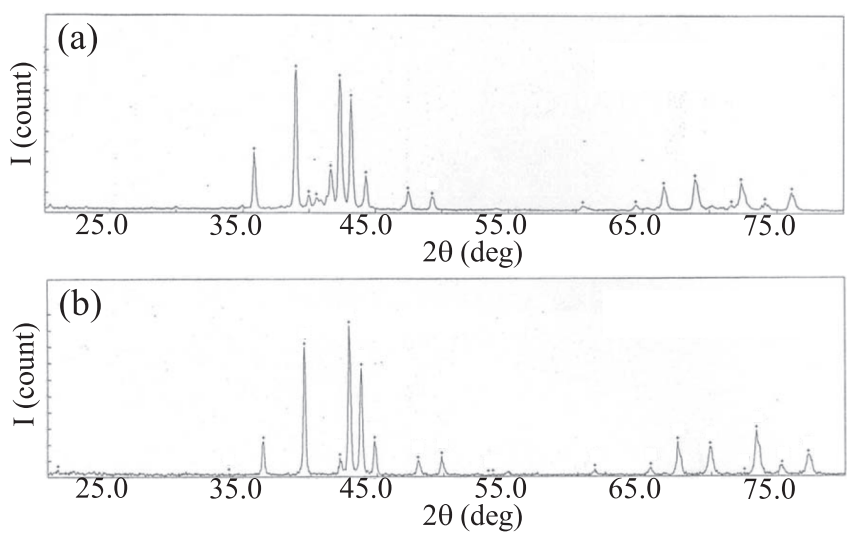

Fig. 16 XRD patterns of $\mathrm{Ti}_{25} \mathrm{Zr}_{10} \mathrm{~V}_{15} \mathrm{Mn}_{50}$ (a) with and (b) without a rapid solidification process.
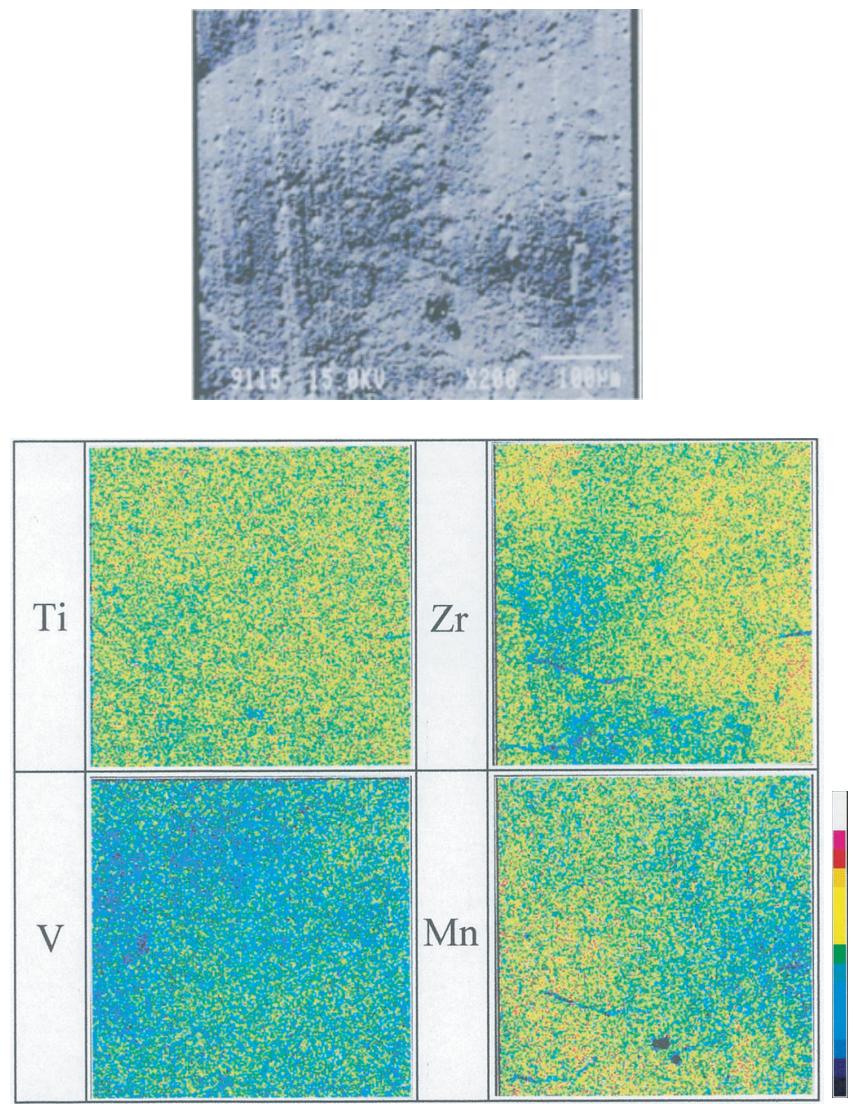

Fig. 17 An optical microscope image with the elemental analysis by EPMA of $\mathrm{Ti}_{25} \mathrm{Zr}_{10} \mathrm{~V}_{15} \mathrm{Mn}_{50}$ with a rapid solidification process.
トーの傾きを改善できることがわかった，さらに，現存の C14 ラーベス合金の中でも最も良好な特性を持つ合金の $1 つ$ を見出すことに成功した.

\section{4. 結言}

本研究では, $\mathrm{AB}_{2}$ 型合金の中でも最大水素吸蔵量が大き く, 比較的優れた水素吸放出特性を有する TiMnV 三元系合 金に着目し，水素化特性の改善を図った。

まず, TiMnV 三元系合金の組成を広範囲に渡って調査し, その結晶構造を把握した結果, 組成によって C14 ラーベス 単相, BCC 単相, C14 ラーベス $+\mathrm{BCC}$ 混相の 3 つの状態に 分類されることがわかった. その中で, 最も水素吸蔵量が大 きかったのは BCC 単相, プラトー部の平坦性やヒステリシ ス特性が良好であったのは C14 ラーベス単相であり, 混相 はその中間の特性が得られた。

また, 熱処理条件を変化させて結晶構造や水素化特性の違 いを確認した結果, 熱処理温度を 1373 K から 1173 K に下げ ることで, $\mathrm{C} 14$ ラーベス単相の析出範囲は広がることがわ かった. しかし，C14 ラーベス単相を示す合金でも, Ti P V が多い組成では水素化特性の改善には至らなかった。結晶構 造を解析した結果, 水素化物の形成のし易さは変化すること がわかり，特に高温域から低温域まで安定にC14 ラーベス 単相を示す合金にて金属相と水素化物相の二相共存領域が明 確に得られることがわかった。

次に, 水素吸蔵量を更に増大させるため, 添加元素の検討 を行った. 種々元素を置換して水素化特性を調査した結果, 唯一 $\mathrm{Zr}$ の置換のみ, 有効水素移動量の増大効果が確認され た. $\mathrm{Zr}$ 置換により格子体積の増大効果が得られたが, $\mathrm{Zr}$ 置 換前に水素を吸蔵しなかった合金でも $\mathrm{Zr}$ 置換により水素を 吸蔵することが確認された。このことから，この合金系にお

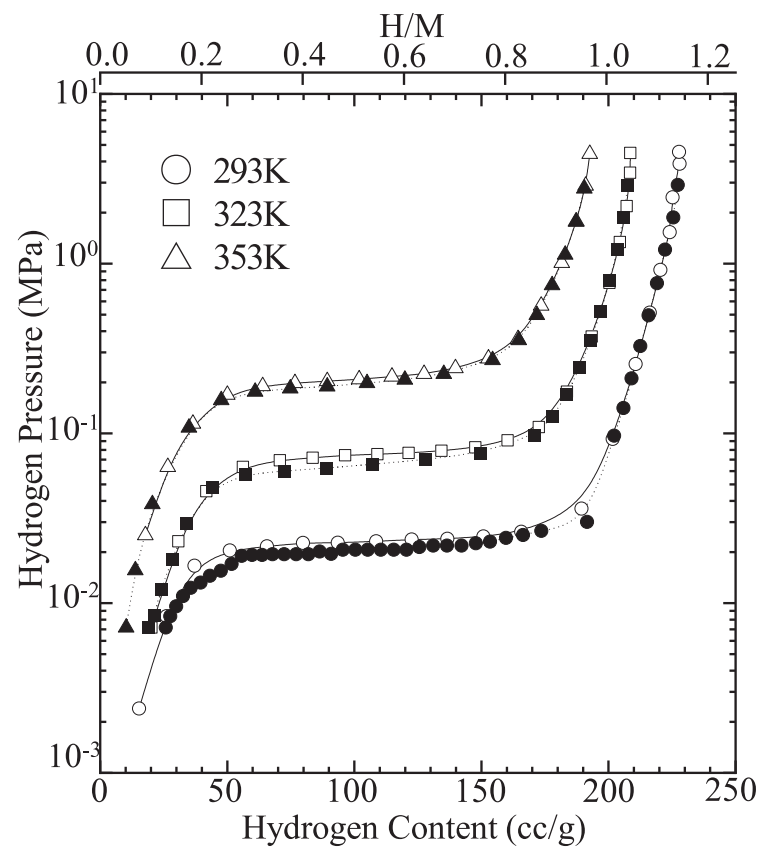

Fig. 18 PC-isotherms of $\mathrm{Ti}_{25} \mathrm{Zr}_{10} \mathrm{~V}_{15} \mathrm{Mn}_{50}$ with a rapid solidification process at $293 \mathrm{~K}, 323 \mathrm{~K}$, and $353 \mathrm{~K}$, where open and closed symbols are absorption and desorption, respectively. 
ける水素吸蔵可能な格子定体積がおよそ $163 \mathrm{~nm}^{3}$ 以上である ことを見出した．また，格子体積が $173 \mathrm{~nm}^{3}$ 以上になるとプ ラトー特性が悪化することも見出した，Zrを置換した合金 にて組成の最適化を行った結果, $\alpha$ 相領域と最大水素吸蔵量 との増減関係から, 有効水素移動量が最大となる組成比を見 出した.

最後に, $\mathrm{Zr}$ 置換量の増大に伴いプラトー部の平坦性が悪 化することを受けて，組織学的調査を実施したところ，プラ トー部の平坦性の悪化は $\mathrm{Zr}$ の偏析に起因することがわかっ た。 そこで，急冷凝固法を用いて合金の作製を試みた。 その 結果, $\mathrm{Zr}$ の偏析を抑制し成分の均質化ができることを見出 した。これにより， $\mathrm{P}-\mathrm{C}-\mathrm{T}$ 特性にも大きな改善効果が表れ た. 現存の $\mathrm{C} 14$ ラーベス合金の中でも最も良好な特性を持 つ合金の 1 つとして, $\mathrm{Ti}_{25} \mathrm{Zr}_{10} \mathrm{~V}_{15} \mathrm{Mn}_{50}$ を見出すことに成功し た.

文献

1) J.H.N. van Vucht, F.A. Kuijpers and H.C.A.M. Bruning: Philips Res.
Rep. 25 (1970) 133-140.

2) J.R. Johnson: J. Less-Common Met. 73 (1980) 345-354

3) T. Yamashita, T. Gamo, Y. Moriwaki and M. Fukuda: J. Japan Inst. Metals 41 (1977) 148-154.

4) T. Gamo, Y. Moriwaki, N. Yanagihara, T. Yamashita and T. Iwaki: Int. J. Hydrogen Energ. 10 (1985) 39-47.

5) B.K. Singh, A.K. Singh, A.M. Imam and O.N. Srivastava: Int. J. Hydrogen Energ. 26 (2001) 817-821.

6) S. Semboshi, N. Masahashi and S. Hanada: J. Alloy. Compd. 352 (2003) 210-217.

7) Y. Li, S. Zheng, F. Fang, H. Zhang, Q. Zhang and D. Sun: J. Mater. Res. 24 (2009) 2886-2891.

8) F. Fang, Y. Li, Q. Zhang, L. Sun, Z. Shao and D. Sun: J. Power Sources 195 (2010) 8215-8221.

9) H. Iba and E. Akiba: J. Alloy. Compd. 253-254 (1997) 21-24.

10) A. Guéguen, J.-M. Joubert and M. Latroche: J. Alloy. Compd. 509 (2011) 3013-3018.

11) Y. Osumi: Shinban suisokyuzogokin-Sono bussei to oyo-, (AGNE Gijutsu Center Inc., Tokyo, 1999) p. 24.

12) M.H. Mendelsohn, D.M. Gruen and A.E. Dwight: Nature 269 (1977) 45-47.

13) M.H. Mendelsohn, D.M. Gruen and A.E. Dwight: J. Less-Common Met. 63 (1979) 193-207.

14) S.B. Gesari, M.E. Pronsato, A. Visintin and A. Juan: J. Phys. Chem. C 114 (2010) 16832-16836. 